\title{
Influence of Role Model Factors on Women Entrepreneurial Participation in Agriculture (A Case Study of Kebbi and Sokoto States, Nigeria)
}

\author{
Mulikat Folashade Usman \& Mairo Abdullah \\ Department of Business administration, Faculty of Management Sciences, Usmanu Danfodiyo University Sokoto, Nigeria
}

\begin{abstract}
This study was carried out to examine the influence of role model factors on women entrepreneurial participation in Kebbi and Sokoto States of Nigeria. Primary data were obtained from a sample of 500 women entrepreneurs via questionnaire and analysed using binary logistic regression. Out of the six factors investigated, only three were found to influence women entrepreneurial participation in agriculture in Kebbi and Sokoto States. These are $X_{1}=$ "I got influenced by someone to start my business", $X_{4}=$ "I received support and guidance when starting my business", $X_{3}=$ "I admire people who have succeeded in business". The other three, namely, $X_{2}=$ " The person who influenced my decision owns a business", $X_{5}=$ "I am of the same sex with the person who influenced $m y$ decision", $X_{6}=$ "I learnt various skills from the person who influenced my decision" were not found to influence women entrepreneurial participation in Kebbi and Sokoto States. Results showed that $X_{3}$ and $X_{4}$ were positively related to women entrepreneurial participation, while $X_{1}$ has negative correlation with women entrepreneurial participation, whereas, $X_{5}$, and $X_{6}$ do not have influence on women entrepreneurial participation. Findings suggest that Government and the policy makers should collaborate with the successful entrepreneurs in Agriculture to help enlightening new interested entrepreneurs who are about to venture into agriculture business to boost their knowledge in the sector which enhance their productivity.
\end{abstract}

Keywords: Role model, Women Entrepreneurs, Logistic Regression, Participation.

\section{INTRODUCTION}

A role model is an important socio-cultural factor that influences women entrepreneurship as the presence of successful entrepreneurs helps to inspire others to venture into entrepreneurship. The relevance of role models to entrepreneurs or potential entrepreneurs is evident in the popular business press that is littered with stories of, and references to, entrepreneurial endeavours and successes that have influenced other entrepreneurs. As stated by Niels, Jolanda, Veronique, Mirjam and Ingrid, (2011), many entrepreneurs claim that their business start-up decision and the development of their business have been influenced by others. These 'others' are often entrepreneurs and may range from famous people such as Steve Jobs to former colleagues or family members. Role models may, for example, be icons with whom the entrepreneur is not familiar on a personal basis, models such as Mrs. Folorunsho Alakija, Alhaji Aliko Dangote or Bill Gates, who have distinguished themselves in entrepreneurship. Alternatively, the relationship can be more personal, if the role model belongs to the entrepreneur's direct environment, such as family or friends with whom there are strong ties or to the entrepreneur's wider environment, such as former employers or colleagues (weaker ties).

A role model is a common reference to individuals who set examples to be emulated by others and who may stimulate or inspire other individuals to make certain (career) decisions and achieve certain goals (Wright et al., 1997; Basow and Howe, 1980; Shapiro et al., 1978). Role models have been known to have a profound influence on career decisions in all aspects of life (Krumboltz et al., 1976). Therefore, role models may also enhance the desire to become an entrepreneur and the entrepreneurial self-efficacy of individuals (Van Auken et al., 2006a; 2006b). This may, in turn, positively influence entrepreneurial intentions and, ultimately, entrepreneurial activity (Krueger et al., 2000).

Niels et al (2011) also revealed that a strand of literature indicating that role models are associated with the decision to become an entrepreneur is obtained from a more aggregate perspective than that of the individual. Research at the regional level has shown that entrepreneurship is spread unevenly and that this regional variance in entrepreneurship is often persistent (Reynolds et al., 1994). Several studies have attributed these differences between clusters, regions and countries to the existence and availability of role models (Sternberg, 2009; Lafuente et al. 2007; Fornahl, 2003).

In addition, role models may provide entrepreneurs with actual practical support and advice as a mentor to a mentee, learning by support (Nauta and Kokaly, 2001). Gibson (2004) states that the importance of role models lies in three interrelated functions: "to provide learning, to provide motivation and inspiration, and to help individuals define their self-concept". Nauta and Kokaly (2001) add a provisional constituent to the function of role models, arguing that role models not only provide individuals with inspiration and modelling but also with support and guidance.

Building on the theories of role identification and social learning as well as the proposed role model functions by Gibson (2004), it can be concluded that entrepreneurial role models may perform four interrelated functions: 
1. inspiration and motivation, ( role model creates awareness and motivates people to get started),

2. increasing self-efficacy ( role model makes people confident that they too can reach a certain goal),

3. learning by example ( role model provides guidelines for action) and

4. Learning by support (role model provides hands-on support or advice).

The first two functions result (indirectly) from role identification theory whereas the third and fourth are implied by social learning theory.

In the context of the present study, a role model is seen as a worthy entrepreneur who serves as a good example to potential entrepreneurs either within the society or in the immediate environment. The study recognises that role models who may influence women entrepreneurs in kebbi and Sokoto States can be within their immediate family or even beyond their States but with remarkable records of entrepreneurial feats, having confronted and made remarkable achievements in enterprise creation in spite of the prevailing socio-cultural challenges.

The studies of Niels et al. (2011); Mueller (2006) and Davidsson and Wiklund (1997), all show that the presence of other entrepreneurs in a society may legitimize entrepreneurial aspirations, actions and development. Hence, if more entrepreneurs are encouraged to thrive in Kebbi and Sokoto States, it is believed that many more will develop entrepreneurial intentions and actions.

Entrepreneurship has been a male-dominated phenomenon, but time has changed the situation and women have become the most memorable and inspirational entrepreneurs, even in traditionally male dominated sectors such as construction (Vinesh, 2014), transportation, real estate, technology and energy. Entrepreneurship has been recognised as a fundamental force for economic change that requires more women to be involved in because very little is known about the economic relevance of women's entrepreneurship. The policy instrumentsthat are effective in raising entrepreneurship rates among women and the economic effects of higher participation of women in entrepreneurial activity (Okafor \& Mordi, 2010). Dharmendra (2014) advanced that women entrepreneurship needs to be studied separately for two main reasons; that women's entrepreneurship has been recognized in the last decade as an important untapped source of economic growth; that women entrepreneurs not only create new jobs for themselves and others but also provide society with different solutions to management, organization and business problems as well as the exploitation of entrepreneurial opportunities in varied sectors.

Yusuf (2013) and Eren (2012) submit that women entrepreneurs are often marginalized in the informal sector and lack the capacity to develop their business, to create jobs and increase productivity due to the barriers that exist between them and men entrepreneurs. Entrepreneurial activities in most countries are male dominated especially in developing countries where the ratio of women entrepreneurs to men entrepreneurs differs noticeably across the world (Eren, 2012). Women entrepreneurs run within gender bias in the midst of other constraints that can either be a threat or create opportunity for women entrepreneurs (Eren, 2012).

According to Noguera (2012), most women entrepreneurship studies, Brush (1992:13), identify gender differences with respect to individual characteristics and suggest that 'women business owners are more different from, than similar to, men in terms of individual level characteristics such as education, occupational experience, motivations, and circumstances of business start-up/acquisition'. Gender discrimination against women entrepreneurs is usually revealed in socio-ethnic practices, for example, the Igbos of the South East of Nigeria are known to be the foremost entrepreneurial groups when compared to other major ethnic groups in Nigeria (Yusuf, 2013). The Igbos are known to operate business enterprises in virtually every part of Nigeria. In Sokoto State, the typical Muslim Hausa women are often secluded and barely come out to engage fully in enterprise running, whereas, their Igbo counterparts are fully engaged in one business or the other in spite of apparent negative socio-cultural and gender constraints. The researcher has often wondered whether the typical Igbo entrepreneur was born with the "business gene".

However, the entrepreneurial activities as practiced in the Igbo ethnic group of Nigeria give priority to the training of the male child for entrepreneurial activities. The male child as a custom is given entrepreneurial orientation and training right from childhood, while the female child is seen to provide future supportive role to their husbands or family business. This is evidenced according to Nworah (2011) by the fact that at demise of an entrepreneur in Igbo ethnic group the practice is usually the transfer of control of his enterprise to the eldest male child who may even be the least competent. This constitutes a bias against women entrepreneurs.

Abimbola and Agboola (2011) view gender as a force found to be capable of either hampering or facilitating entrepreneurial activities in any society. The issue of gender factor affects women entrepreneurs positively and negatively, depending on the economy and nation (Yusuf, 2013). However, gender bias affect participation of women in the formal sector of entrepreneurial activities; this is evidence in Malaysia where the Malay constitute $70 \%$ of the population, but, only two (2) women entrepreneur are listed out of fourteen (14) most successful Malay entrepreneurs making waves in the Asian economy. The report indicates that fewer Malay women entrepreneurs are involved in the formal economic sector, while, women entrepreneurship activities thrive better in a conducive atmosphere. Discrimination against women entrepreneurs is experienced much more severely in Africa and indeed the developing countries than in developed countries due to cultural practices, religious bias, discrimination and tradition of cultural bias (Yusuf, 2013). 
Naude and Minniti (2011) opine that gender gaps in start-up are much larger in developing economies while tending to be narrower in developed economies. This may be due to many women starting business out of necessity. However, Yusuf (2013) observes that women have started business significantly in greater number over the past two decades, but gender inequality still remains prominent when compared to the traditional labour market.

Studies on women entrepreneurship in the developing countries are still underdeveloped and fragmented according to Singh, Mordi, Okafor and Simspson (2010). They equally noted that whereas a lot is known about female entrepreneurs in developed economies, the research on challenges to female entrepreneurial advancement in transitional economies such as Nigeria is limited. Besides, not only are most of the studies concentrated in developed countries and regions, different research designs and methodologies have been employed.

For example, employing cross-sectional and case study research designs in which 80 women entrepreneurs in the small and medium enterprises were surveyed using the questionnaire, Petro, Annastazia \& Robert (2014) examined the effects of socio-cultural factors on the performance of women's small and medium enterprises in Tanzania and found that social and cultural factors negatively affect the performance of women entrepreneurial participation, implying that women entrepreneurs cannot perform outstandingly under such social and cultural factors. Data were analysed using descriptive statistics and binary logistic model and it was concluded that generally, family roles, level of education, role models, women immobility, poor support from society members and ethnicity negatively affect the performance of women entrepreneurs. Although their study addressed the influence of socio-cultural factors on women entrepreneurs, they failed to explore the sectoral dimension of women entrepreneurial activity.

Similarly, Tundui (2012), investigated the relationship between gender and small businesses involving 310 entrepreneurs in Tanzania, and found that "women are unlikely to aim high as compared to men due to different socialization experiences." Nawaz (2009) and Nchimbi (2002) in their separate studies cited normative factors including social dishonour of women especially in rural areas as barriers to women who venture into entrepreneurship.

Most of these studies, as observed by Petro, Annastazia \& Robert (2014), focused on establishing how socio-cultural factors affect women entrepreneurial behaviour without specifically investigating the impact of factors like role model on women entrepreneurship in different sectors. The extent to which women-owned business performance in different sectors can be explained by different types of role model factors has therefore not been adequately explored. Therefore, this study evaluates the impact of role model factors on women entrepreneurial participation in the agriculture sector in Kebbi and Sokoto States.
Of the numerous studies conducted to explore the relationship between women entrepreneurial activity and role-model factors only few have been recorded with focus on Nigeria and in fact, North-western Nigeria. ). This create a geographical gap which the present study seeks to fill by evaluating the influence of role model factors on women entrepreneurial participation in agriculture sector in kebbi and sokoto states of Nigeria.

This study attempts to find out whether influence of role model factors could have a profound influence on career decisions in all aspects of life. In addition, we expect a priori, that a woman's role model in kebbi and sokoto states determines to an extent her degree of entrepreneurial participation in agricultural sector.

Literature has yet to show whether entrepreneurs have homophilic role models, that is, models who are similar to themselves in terms of characteristics such as nationality and gender, or whether they select role models that are different and/or enterprising with a more ambitious scope and level (Kim and Aldrich, 2005; Ruef et al., 2003. ).

The limited amount of academic research on role model factors in Nigeria and specifically, in Kebbi and Sokoto states. The present study seeks to explore some of these underlying issues.

It is against this background that the present study undertakes the influence of role model factors on women entrepreneurial participation in agricultural sector in Kebbi and Sokoto States. To achieve this, this study is structured into five sections. Section one is the brief introduction, followed by the literature review and hypothesis development in section two, section three discusses the methodology. Section four discusses the results and both recommendations and conclusions were drawn in section five.

\section{Research Questions}

1. To what extent do role-model factor $($ ISMB $)=I$ got influenced by someone to start my business, influence women entrepreneurial participation in the Agriculture) sector in Kebbi and Sokoto States?

2. To what extent do role-model factor $(\mathrm{PIDB})=$ The person who influenced my decision owns a business, influence women entrepreneurial participation in the Agriculture) sector in Kebbi and Sokoto States?

3. To what extent do role-model factor $($ RSGB $)=\mathrm{I}$ received support and guidance when starting my business influence women entrepreneurial participation in the Agriculture) sector in Kebbi and Sokoto States?

4. To what extent do role-model factor, $($ APSB $)=I$ admire people who have succeeded in business, influence women entrepreneurial participation in the Agriculture) sector in Kebbi and Sokoto States? 
5. To what extent do role-model factor $(\mathrm{SSPD})=\mathrm{I}$ am of the same sex with the person who influenced my decision, have significant influence on women entrepreneurial participation in the Agriculture) sector in Kebbi and Sokoto States?

6. To what extent do role-model factor $($ LSPD) $=$ I learnt various skills from the person who influenced my decision), have significant influence on women entrepreneurial participation in the Agriculture) sector in Kebbi and Sokoto States?

\section{Objective of the Study}

The broad aim of the study is to examine the influence of role model factors on women entrepreneurial participation in the agriculture sector in Kebbi and Sokoto states, Nigeria. The specific objective of the study is to:

1. To determine the how role-model factor $($ ISMB $)=I$ got influenced by someone to start my business, affect women entrepreneurial participation in the Agriculture) sector in Kebbi and Sokoto States?

2. To determine how role-model factor model factor ((RSGB) $=\mathrm{I}$ received support and guidance when starting my business affect women entrepreneurial participation in the Agriculture) sector in Kebbi and Sokoto States?

3. To assess how the role model ( PIDB) ) factor $=$ The person who influenced my decision owns a business, affect women entrepreneurial participation in the Agriculture) sector in Kebbi and Sokoto States?

4. To determine how the do role-model factor, $($ APSB $)=I$ admire people who have succeeded in business, affect women entrepreneurial participation in the Agriculture) sector in Kebbi and Sokoto States?

5. To examine the extent to which role-model factor $(\mathrm{SSPD})=$ I am of the same sex with the person who influenced my decision, affect women entrepreneurial participation in the Agriculture) sector in Kebbi and Sokoto States?

6. To determine the degree of the relationship between rolemodel factor $($ LSPD $)=$ I learnt various skills from the person who influenced my decision), and women entrepreneurial participation in the Agriculture) sector in Kebbi and Sokoto States?

\section{Research Hypotheses}

This research question was translated into the following research hypothesis:

There is no significant relationship between the six role model factors (ISMB, PIDB, RSGB, APSB, SSPD, LSPD) and women entrepreneurial participation in the Agricultural sector in Kebbi and Sokoto States.

\section{Scope of the study}

This study focused on the role- model factors affecting women entrepreneurial participation in agriculture sector in Kebbi and Sokoto states, Nigeria.

\section{Significance of the study}

The study investigates the role- model factors influencing women entrepreneurial participation in the agriculture sector in Kebbi and Sokoto States of Nigeria and so, provides robust theoretical and empirical information to broaden the horizon of both women entrepreneurs and all stakeholders, particularly in Kebbi and Sokoto States, Nigeria.

\section{LITERATURE REVIEW}

This section takes a look at socio-cultural constraints to women entrepreneurship and reviews relevant literature on the relationship between entrepreneurial participation and sociocultural factor such as role model factors.

Extant literature identifies quite a number of constraints that women face in their quest to start and grow their own businesses and a number of these challenges are chiefly sociocultural. The study of Mauchi, Mutengezanwa and Damiyano (2014) reveals that many socio-cultural constraints inhibit the efficient conduct of business by women in various business sectors.

Mercy's (2013) study of female enterprise development in Kenya found that the obstacles encountered at the start-up and development stages of female owned enterprises are access to finance, finding the right contacts and business network, lack of entrepreneurship education, lack of management skill, lack of advice on how to start enterprise, lack of mentoring and lack of business strategy planning. Her study is very relevant to this work except that she did not discuss family context, ethnicity and religious practices in her study.

Mwaura, Gathenya and Kihoro (2015) in their study of the influence of entrepreneurial orientation on the performance of women owned enterprises in Kenya, found that entrepreneurial orientation plays a major role on the performance of enterprises. They recommended that there is need for the government of Kenya at the national and county levels private sector, the women entrepreneurs and all stakeholders to partner and create opportunities for women to form trade associations, attend seminars and conferences and have publications and institutions that provide courses that aid the entrepreneurs to acquire entrepreneurial orientation.

Byrne and Janice (2019) studied role-models and women entrepreneurs: Entrepreneurial Super Woman Has Her Say. The study analyse the narratives of 51 role- model women entrepreneurs to explore how they represent women entrepreneurs and entrepreneurship, the study found that in accordance with the contemporary pressure for women to succeed and perform personally and professionally, the voice of the ( super) woman doing "individualized entrepreneurial feminity" dominates. The role models narratives obscure race, class and age barriers reproduce prevailing gender stereotypes, normalize discriminatory workplace treatment and depict entrepreneurship as an appropriate alternative for working mothers. 
Cacagna et al. (2020) studied the differences in firm characteristics and performance between crossover and noncrossover female entrepreneurs. The study found that $63 \%$ of female entrepreneurs who had crossover reported that they had role models compared with $54 \%$ of non-crossover. On average, $35 \%$ of the role models were men, fathers were the common male role models. Report indicated that if women entrepreneurs have role models who support them, they are $6.5 \%$ more likely to crossover, compared with women who have no role models.

Using a questionnaire with an extensive set of questions about the role models that influenced entrepreneur's decision to start a company (pre-start-up phase) and the progress in years 1-3 of the firm's life cycle (post-start-up phase), Niels et al. (2011) conducted a broad explorative empirical study based on data collected from a sample of 292 owners of Dutch young businesses. Out of the 292 entrepreneurs who were interviewed, 159 (54\%) had role model. This 54 percent was divided into a group of 20 percent with role models in the prestart-up phase only, 10 percent with role models in the poststart-up phase only, and 24 percent with a role model in both phases. Thus, in total, the entrepreneurs had 229 role models. However, only $28 \%$ of the entrepreneurs with role models (fully) agreed that their role models have been of crucial importance for undertaking the venture (pre-start-up) or continuing it (post-start-up).

While 'learning by example' remains the dominant function of role models as viewed by the entrepreneurs, identified functions of role models ('learning by support', 'increasing entrepreneurial self-efficacy' and 'inspiration/motivation') are also important (perceived) and highly valued both before and after the start-up of the entrepreneurs' companies. The results of their analyses also show that many entrepreneurs thought that their role models fulfilled important functions and a significant part of them even claimed that they would not have started (or continued) their business without their role model. With 68 percent of the entrepreneur-role model combinations in the pre-start-up and post-start-up phases being of the same gender, their empirical results also indicate that entrepreneurs tend to have role models of the same gender. In addition, $80 \%$ of the entrepreneurs have role models with the same nationality ( $84 \%$ close home and with personal contacts) and $40 \%$ of the entrepreneurs with role models operate in the same sector as their role models. Although this is a robust research, the limitation of the study is that descriptive statistics to depict gender peculiarities for women entrepreneurs and the impact of their role models were not provided.

Role models serve as a common reference to individuals and set examples to be emulated by others and they also stimulate or inspire other individuals to make certain (career) decisions and achieve certain goals (Wright, Wong, and Newill, 1997; Basow and Howe, 1980 and Shapiro, Haseltine and Rowe 1978). According to Krumboltz, Mitchell and Jones (1976), role models could have influence on decisions, which could also improve the aspiration to become an entrepreneur and the entrepreneurial self-efficacy of individuals (Van Auken and Stevenss 2006), which may, in turn, positively influence entrepreneurial intentions and ultimately entrepreneurial activity.

There exists a strong connection between the presence of role models and the emergence of entrepreneurs (Shapero \& Sokol, 1982) and women as they historically have not been present as entrepreneurs in general lack close role models. Role models are persons that by their attitudes, behaviours and actions establish the desirability and credibility of a choice (in this case of becoming an entrepreneur) for an individual. Furthermore, the influence of role models is gender related. That is, an individual will be more influenced by another individual of the same sex, as one's aspirations and choices tend to be more influenced by persons of the same sex (Deaux and Lafrance, 1998). This is a result that has been replicated in different countries by employing different methods. An example of the importance of role models is the well-known fact in entrepreneurship research that children of self-employed parents are over-represented among firm owners and those trying to start a business. There also seems to be some evidence suggesting that whereas occupational inheritance declines with economic development, it still persists at a high level among self-employed or entrepreneurs. Hence it is a known fact that the success of the self-employed parent is of central importance to the child's perception of entrepreneurship as a career option. In particular, individuals who are children to parents perceived as being successful entrepreneurs are more likely to choose entrepreneurship as a career than individuals who perceive their parents as being less successful or have parents who are not self-employed (Davidsson, 1995; Delmar \& Gunnarsson, 2000; Scherer, Brodzinski \& Wiebe, 1991). Furthermore, Davidsson, (1995)also reported that the influence of self-employed parents is gender specific, i.e a son is more likely to become self-employed if the father was self-employed, than a daughter would be. According to Bandura's Social Cognitive theory, role models create interest and critical experience. This basic argument has been adapted to career choice behaviour by Lent, Brown and Hackett (1994). The theory specifies that interests, academic and career choice options and performance and persistence in educational and occupational options are influenced by the person's self-efficacy and outcome expectations. Personal factors, learning experiences and contextual background have an effect on a person's selfefficacy. In terms of self-employment, a person chooses to become self-employed because he or she feels confident in that area; this confidence leads to an interest in selfemployment. The person's confidence is shaped by his/her contextual factors such as ethnicity, age, gender, support system and past learning experiences. Specifically, acculturation, family socio-economic background and family involvement influence self-efficacy. Perceived self-efficacy has been proposed as a central concept in entrepreneurship (Boyd \& Vozikis, 1994) because it is proximal in nature and has been proven to be associated with initiating and persisting 
in achievement-related behaviours such as business settings (Wood \& Bandura, 1989). Perceived self-efficacy has been found to be positively related to the intention of starting one's own business and exploring new opportunities (Chen, Gene Greene, \& Crick, 1998; Krueger \& Dickson, 1993; Krueger \& Dickson, 1994). From this perspective then, parents function as carriers of values, emotions and experiences towards selfemployment. More specifically, self-employed parents provide the child (whether adult or not) with plenty of vicarious experience. Vicarious experience is the second-best way of learning, after individually enacted mastery experiences. Vicarious experience affects self-efficacy because it enables the person to judge one's perceived capabilities in relation to the attainment of others. Working in a small firm enables a person to gain both mastery experience and vicarious experience.

However, the mastery experience comes from learning and mastering the trade and the vicarious experience from observing the management of the small firm. The greater the assumed similarities between the role model and the observer, the more persuasive are the role model's successes and failures. If people see the role models as very different from themselves, their perceived self-efficacy will not be heavily influenced by the model's behaviour and performance. Hence, parents (of the same gender) are persuasive as role models because the child can assume close similarity. It is however worth noting that the match between entrepreneurs and their role models has not yet been studied. Apart from conceptual studies establishing a link between role models and entrepreneurial intentions and development, empirical research on the importance of role models for (nascent) entrepreneurship has been scarce and there is still little knowledge of what determines the use of specific entrepreneurial role models, as well as the precise function of such role models (Niels et al., 2011).

Apparently, many role model factors influence women entrepreneurial participation. In the present study, therefore, we hypothesize that there is no significant relationship between role model factors: ISMB, RSGB, PIDB, APSB, SSPD, LSPD and women entrepreneurial participation in agriculture sector in Kebbi and Sokoto States.

\section{METHODOLOGY}

Inferential statistics was used to analyze the data. A binary logistic regression is an appropriate statistical analysis in this study as the purpose of the research is to determine whether the independent variable (role model factors) predicts the dichotomous, dependent variable (women entrepreneurial participation in agriculture (coded 1) and others (coded 0) sectors). In this study, the independent variables are role model factors. This analysis permits the evaluation of the odds of membership in one of the two groups based on the combination of predictor variable values. Evaluation of the logistic regression model includes the overall model evaluation (the percentage of correct predictions). The overall model significance for the logistic regression was examined by the influence of the explanatory variables (with the $\chi^{2}$ coefficient). The Nagelkerke $\mathrm{R}^{2}$ was examined to assess the percent of variance accounted for by the explanatory variables. Predicted probabilities of an event occurring will be determined by exponential beta $[\operatorname{Exp}(\beta)]$, which is a measure of the regression coefficient.

The empirical logistic model for analyzing the role model factors influencing women entrepreneurial participation in Kebbi and Sokoto States is specified as follows:

\section{Measurement of Variables}

There are two types of variables in this work, the dependent and independent variables which were measured as follows in the Table 1;

\section{Dependent Variable (Women Entrepreneurial Participation)}

The dependent variable is women entrepreneurial participation (WEP) in different sectors, namely: agriculture and other sectors. Following the Global Entrepreneurship Monitor (GEM) (2010) project, women entrepreneurial participation in the different sectors was measured by the number of women-owned enterprises in the various sectors in Kebbi and Sokoto States of North-western Nigeria. This was gotten from the Small Medium Enterprises Development Agency of Nigeria (SMEDAN) reports for both Kebbi and Sokoto States.

\section{Independent Variables (Role-Model Factors)}

Role model is defined as a common reference to individuals who set examples to be emulated by others and who may stimulate or inspire other individuals to make certain (career) decisions and achieve certain goals (Basow and Howe, 1980). A 5-point Likert scale was used to obtain information on the perceived influence of role model factors on women entrepreneurial participation in Kebbi and Sokoto States of North-western Nigeria. Role model was measured on the basis of I got influenced by someone to start my business, PIDB) = The person who influenced my decision owns a business, $($ RSGB $)=$ I received support and guidance when starting my business, $($ APSB $)=$ I admire people who have succeeded in business, $(\mathrm{SSPD})=\mathrm{I}$ am of the same sex with the person who influenced my decision, ( LSPD) = I learnt various skills from the person who influenced my decision).

Table 1: Description of Variables

\begin{tabular}{|c|c|c|c|}
\hline Variable Name & Variable Type & Scale & $\begin{array}{c}\text { Variable } \\
\text { Measurement }\end{array}$ \\
\hline $\begin{array}{c}\text { Women } \\
\text { entrepreneurial } \\
\text { participation in } \\
\text { Agriculture sector } \\
Y\end{array}$ & Dependent & Nominal & $\begin{array}{c}\text { If yes=1, No = } \\
0\end{array}$ \\
\hline $\begin{array}{c}\text { I got influence by } \\
\text { someone to start } \\
\text { my business }\left(\mathrm{X}_{1}\right)\end{array}$ & Independent & Continuous & $\begin{array}{c}\text { 5-point likert } \\
\text { scale }\end{array}$ \\
\hline $\begin{array}{c}\text { The person that } \\
\text { influence my }\end{array}$ & Independent & Continuous & $\begin{array}{c}\text { 5-point likert } \\
\text { scale }\end{array}$ \\
\hline
\end{tabular}




\begin{tabular}{|c|c|c|c|}
\hline $\begin{array}{c}\text { decision owns a } \\
\text { business }\left(\mathrm{X}_{2}\right)\end{array}$ & & Continuous & $\begin{array}{c}\text { 5-point likert } \\
\text { scale }\end{array}$ \\
\hline $\begin{array}{c}\text { I admire people } \\
\text { who have } \\
\text { succeeded in } \\
\text { business }\left(\mathrm{X}_{3}\right)\end{array}$ & Independent & Continuous & $\begin{array}{c}\text { 5-point likert } \\
\text { scale }\end{array}$ \\
\hline $\begin{array}{c}\text { I receive support } \\
\text { and guidance } \\
\text { when starting my } \\
\text { business }\left(\mathrm{X}_{4}\right)\end{array}$ & Independent \\
\hline $\begin{array}{c}\text { I am of the same } \\
\text { sex with the } \\
\text { person who } \\
\text { influence my } \\
\text { decision }\left(\mathrm{X}_{5}\right)\end{array}$ & Independent & Continuous & $\begin{array}{c}\text { 5-point likert } \\
\text { scale }\end{array}$ \\
\hline $\begin{array}{c}\text { I learnt various } \\
\text { skills from the } \\
\text { person who } \\
\text { influence my } \\
\text { decision }\left(\mathrm{X}_{6}\right)\end{array}$ & Independent & Continuous & $\begin{array}{c}\text { 5-point likert } \\
\text { scale }\end{array}$ \\
\hline
\end{tabular}

$y=\frac{e^{B_{0}+B_{1} x_{1}+B_{2} x_{2}+B_{3} x_{3}+B_{4} x_{4}+B_{5} x_{5}+B_{6} x_{6}}}{1+e^{B_{0}+B_{1} x_{1}+B_{2} x_{2}+B_{3} x_{3}+B_{4} x_{4}+B_{5} x_{5}+B_{6} x_{6}}}$ 4.1)

Where; $B_{i}$
variables

$B_{i}(i=1,2,3,4,5,6)=$ Coefficients of Independent

The above equations explain the extent to which role model motivate women to participate in entrepreneurial activities in the agriculture and other sector.

\section{RESULTS AND DISCUSSION}

In this section, the results and discussion of analyses were presented

Table 2: Logistic Regression Results

\begin{tabular}{|c|c|c|c|c|c|c|c|}
\hline \multicolumn{2}{|c|}{$\begin{array}{c}\text { Independent } \\
\text { Variables }\end{array}$} & B & S.E. & Wald & Df & Sig. & $\begin{array}{c}\operatorname{Exp}( \\
\text { B })\end{array}$ \\
\hline \multirow{7}{*}{} & $\mathrm{X}_{1}$ & -.460 & .131 & 12.352 & 1 & .000 & .631 \\
\cline { 2 - 8 } & $\mathrm{X}_{2}$ & .135 & .135 & .993 & 1 & .319 & 1.144 \\
\cline { 2 - 8 } & $\mathrm{X}_{3}$ & .344 & .106 & 10.411 & 1 & .001 & 1.410 \\
\cline { 2 - 8 } & $\mathrm{X}_{4}$ & .256 & .094 & 7.356 & 1 & .007 & 1.292 \\
\cline { 2 - 8 } $1^{\mathrm{a}}$ & $\mathrm{X}_{5}$ & .047 & .088 & .291 & 1 & .590 & 1.049 \\
\cline { 2 - 8 } & $\mathrm{X}_{6}$ & .026 & .087 & .092 & 1 & .762 & 1.027 \\
\cline { 2 - 8 } & $\begin{array}{c}\mathrm{Co} \\
\mathrm{nst} \\
\text { ant }\end{array}$ & -1.809 & .381 & 22.576 & 1 & .000 & .164 \\
\hline
\end{tabular}

Hypothesis $1\left(H_{01}\right)$ : There is no relationship between enterprenuerial participation in agriculture and role model factor $X_{1}$ (I got influence by someone to start my business)

Result of analysis in Table 2 indicates that there is a significant relationship between entrepreneurial participation in agriculture and role model factor $\mathrm{X}_{1}$ (p-value $=0.000<$ $0.05)$ at the $5 \%$ level of significance. The null hypothesis $\left(\mathrm{H}_{01}\right)$ is therefore rejected) and conclude that there is a significant relationship between entrepreneurial participation and role model factor. Role model factor X1 was negatively correlated with entrepreneurial participation in agriculture in Kebbi and Sokoto States. A unit change in the role model factor (X1) I got influence by someone to start my business by $\mathrm{B}(-.460)$ if other variables are kept constant. The odds of participating in agriculture would decrease by almost $63.1 \%$, and vice versa. $\mathrm{X}_{1}$ (Getting influenced by someone to start a business) is therefore a negative determinant of entrepreneurial participation in agriculture in Kebbi and Sokoto States. The result is in agreement with the sstudies of Niels et al. (2011); Mueller (2006) and Davidsson and Wiklund (1997), and Cacagnat.E. et al (2020) all show that the presence of other entrepreneurs in a society may legitimize entrepreneurial aspirations, actions and development.

Hypothesis $2 \quad\left(\mathrm{H}_{02}\right)$ : There is no relationship between entrepreneurial participation in agriculture and role model factor $X_{2}$ (The person that influence my decision owns a business)

Since $\mathrm{p}$-value $=0.319>0.05$ in the Table 2 , we do not reject the null hypothesis $\left(\mathrm{H}_{02}\right)$. Hence there is no sufficient evidence to say that $X_{2}$ is a determinant of entrepreneurial participation in agriculture in Kebbi and Sokoto States.

Hypothesis $3 \quad\left(\mathrm{H}_{03}\right)$ : There is no relationship between enterprenuerial participation in agriculture and role model factor $X_{3}$ (I admire people who have succeeded in business)

Results in Table 2 show that the variable, $X_{3}$ is a significant predictor of entrepreneurial participation in agriculture at the $5 \%$ level of significance ( $\mathrm{p}$-value $=0.01<0.05$ ). The null hypothesis $\left(\mathrm{H}_{03}\right)$ is therefore rejected. The variable, $\mathrm{X}_{3}$ (I admire people who have succeeded in business) was positively correlated with entrepreneurial participation in agriculture. A unit increase in the factor of entrepreneurial participation in agriculture by approximately $41 \%$ if other variables are kept constant. The odds ratio of 1.41 shows that a one unit increases in $\mathrm{X}_{3}$ ( $\mathrm{I}$ admire people who have succeeded in business) increases the likelihood of entrepreneurial participation in agriculture by approximately $41 \% . \mathrm{X}_{3}$ (I admire people who have succeeded in business) is therefore a significant positive determinant of entrepreneurial participation in agriculture in Kebbi and Sokoto States. ). This result is however in agreement with (Krumboltz et al., 1976) and Janice Byrne et al (2019) who postulated that role models have been known to have a profound influence on career decisions in all aspects of life.

Hypothesis $4 \quad\left(H_{04}\right):$ There is no relationship between enterprenuerial participation in agriculture and role model $X_{4}$ (I receive support and guidance when starting my business)

Results in Table 2 show that the variable, significant predictor of entrepreneurial participation in agriculture in Kebbi and Sokoto States at the $5 \%$ level of significance $(\mathrm{p}$-value $=0.007$ $<0.05)$. The null hypothesis $\left(\mathrm{H}_{04}\right)$ is therefore rejected. The variable, $X_{4}$ was positively correlated with women entrepreneurial participation in agriculture in Kebbi and 
Sokoto States. This means that if other variables are held constant, with a unit increase in the factor $X_{4}$ (I receive support and guidance when starting my business), with an odds ratio of 1.292 , a one unit increase in the factor of $X_{4}$ would increase the odds of women entrepreneurial participation in agriculture by approximately $25.6 \% . X_{4}(I$ receive support and guidance when starting my business) is therefore a positive determinant of women entrepreneurial participation in agriculture in Kebbi and Sokoto States. The result is in consonance with Van Auken et al. (2006a; 2006b) who reported that role models may also enhance the desire to become an entrepreneur and the entrepreneurial self-efficacy of individuals. This may, in turn, positively influence entrepreneurial intentions and, ultimately, entrepreneurial activity (Krueger et al., 2000).

Hypothesis $5\left(H_{05}\right)$ : There is no relationship between role model factor ands entrepreneurial participation in agriculture and $X_{5}$ (I am of the same sex with the person who influence $m y$ $\underline{\text { decision) }}$

As evidenced in Table 2 with $\mathrm{p}$-value $=0.59>0.05$, we do not reject the null hypothesis $\left(\mathrm{H}_{05}\right)$. Hence there is no sufficient evidence to say that $X_{5}$ (I am of the same sex with the person who influence my decision) is a determinant of women entrepreneurial participation in agriculture in Kebbi and Sokoto States.

Hypothesis $6\left(H_{06}\right)$ : There is no relationship between role model factor and entrepreneurial participation in agriculture and $X_{6}$ (I learnt various skills from the person who influence $\underline{\text { my decision) }}$

As evidenced in Table 2 with p-value $=0.762>0.05$, we do not reject the null hypothesis $\left(\mathrm{H}_{06}\right)$. Hence there is no sufficient evidence to say that $X_{6}$ (I learnt various skills from the person who influence my decision) is a determinant of women entrepreneurial participation in agriculture in Kebbi and Sokoto States.

Table 3: Classification Table

\begin{tabular}{|c|c|c|c|c|c|}
\hline \multicolumn{2}{|c|}{ Observed } & \multicolumn{3}{c|}{ Predicted } \\
\cline { 4 - 6 } \multicolumn{2}{|c|}{} & \multicolumn{2}{|c|}{ SECTOR } & $\begin{array}{c}\text { Percenta } \\
\text { ge } \\
\text { Correct }\end{array}$ \\
\cline { 3 - 6 } $\begin{array}{c}\text { Step } \\
1\end{array}$ & $\begin{array}{c}\text { SECTO } \\
\mathrm{R}\end{array}$ & 0 & 346 & 8 & 97.7 \\
\cline { 2 - 6 } & \multicolumn{2}{|c|}{ Overall Percentage } & 133 & 9 & 6.3 \\
\hline \multicolumn{3}{|c|}{ a. The cut value is .500 } \\
\hline
\end{tabular}

Table 3 shows the percentage of correct classification of women entrepreneurial participation in agriculture in Kebbi and Sokoto States due to independent variables $X_{1}, X_{2}, X_{3}, X_{4}$, $X_{5}$ and $X_{6}$. The result shows $71.6 \%$ correct classification. This implies that approximately $72 \%$ of the women under study are influenced to participate in agriculture by the independent variables $X_{1}, X_{2}, X_{3}, X_{4}, X_{5}$ and $X_{6}$ considered in the study.
Table 4: Omnibus Tests of Model Coefficients

\begin{tabular}{|c|c|c|c|c|}
\hline \multicolumn{2}{|c|}{} & Chi-square & Df & Sig. \\
\hline \multirow{3}{*}{ Step 1 } & Step & 26.629 & 6 & .000 \\
\cline { 2 - 5 } & Block & 26.629 & 6 & .000 \\
\cline { 2 - 5 } & Model & 26.629 & 6 & .000 \\
\hline
\end{tabular}

As indicated Table 4 above, the logistic regression model was statistically significant at $5 \%$ level of significance, $\chi^{2}(6)=$ $26.629, p=0.000<0.05$. This means that the six determinants examined had a combined significant effect on entrepreneurial participation in agriculture in Kebbi and Sokoto States. When the predictor variables were evaluated for their individual contribution to the model, it was found that only 3 out of the 6 variables were significant in the model. The 3 variables are $X_{1}$ (Getting influenced by someone to start a business), $X_{3}$ (I admire people who have succeeded in business and $X_{4}$ (I receive support and guidance when starting my business. The 3 variables with no significant contribution to the model are $X_{2}$ (The person that influence my decision owns a business) $X_{5}$ (I am of the same sex with the person who influence my decision) and $X_{6}$ (I learnt various skills from the person who influence my decision).

Table 5: Model Summary

\begin{tabular}{|c|c|c|c|}
\hline Step & $\begin{array}{c}-2 \text { Log } \\
\text { likelihood }\end{array}$ & $\begin{array}{c}\text { Cox \& Snell R } \\
\text { Square }\end{array}$ & $\begin{array}{c}\text { Nagelkerke R } \\
\text { Square }\end{array}$ \\
\hline 1 & $567.377^{\mathrm{a}}$ & .052 & .075 \\
\hline
\end{tabular}

The results from Table 5 show that the model explained $7.5 \%$ (Pseudo $R^{2}$ ) of the variance in women entrepreneurial participation in agriculture in Kebbi and Sokoto States.

\section{CONCLUSIONS AND RECOMMENDATIONS}

Agricultural sector is important to women entrepreneurs as it helps to boost their entrepreneurial output in the society. However, there are factors that influence women entrepreneurs' participation. An empirical investigation of role model factors on women entrepreneurial participation in Kebbi and Sokoto States was carried out using binary logistic regression. The relationship between women entrepreneurial participation and the six role model factors, namely, $x_{1}$ ( I got influence by someone to start my business), $x_{2}$ ( the person that influence my decision owns a business), $x_{3}$ ( I admire people who have succeeded in business), $x_{4}$ (I receive support and guidance when starting my business), $x_{5}$ (I am of the same sex with the person who influence my decision), $x_{6}$ (I learnt various skills from the person who influence my decision), were examined. The study found that two factors $x_{3}$ and $x_{4}$ have positive significant influence on women entrepreneurial participation in Agriculture in Kebbi and Sokoto States. Whereas, three factors, namely, $x 2$ (The person that influence my decision owns a business) $X_{5}$ (I am of the same sex with the person who influence my decision) and $X_{6}$ (I learnt various skills from the person who influence 
my decision) were found not to have influence on entrepreneurial participation in Agriculture in Kebbi and Sokoto States at the $5 \%$ level of significance. Of the six factors, one was found to be negative, viz. $\mathrm{X}_{1}$ (Getting influenced by someone to start a business). This means that $x_{1}$ factor is an inhibitor to women entrepreneurial participation in agriculture in Kebbi and Sokoto States. However $x_{3}$ ( I admire people who have succeeded in business), and $x_{4}$ (I receive support and guidance when starting my business), were found to be positively related to women entrepreneurial participation in agriculture in Kebbi and Sokoto States.

\section{RECOMMENDATIONS}

Based on the results of the analysis, it is recommended that Government and the policy makers should collaborate with the successful women entrepreneurs in Agriculture to help enlightening new interested entrepreneurs who are about to venture into agriculture business to boost their knowledge in the sector which enhance their productivity. Also the Government should focus on skill acquisition for women entrepreneurs to broaden their horizon in agriculture sector. More women entrepreneurs should be encouraged to engage in agriculture sector. Government should give financial support to women entrepreneurs in agriculture sector and educate them through agricultural extension workers and government should help in designing interventions that enable women to be exposed to a successful role model which can help women gain market information.

It is suggested that further studies may be carried out to observe the effects of these determinants on male and female entrepreneurial participation in agriculture in Kebbi and Sokoto States. In addition, others States in North-western Nigeria may be incorporated into future research.

\section{REFERENCES}

[1] Abimbola, O. H., \& Agboola, M. G. (2011). Environmental factors and entrepreneurship development in Nigeria. Journal of Sustainable Development in Africa, 13(4), 170-176

[2] Basow, S., \& Howe, K. (1980). Role-model influence: Effects of sex and sex-role attitude in college students. Psychology of Women Quarterly, 4.

[3] Boyd, N. G., \& Vozikis, G. S. (1994). The influence of selfefficacy on the development of entrepreneurial intentions and actions. Entrepreneurship Theory \& Practice, 18(4), 63-77.

[4] Brush, C. (1992). Research on women business owners: past trends, a new perspective and future directions. Entrepreneurship Theory and practice, 16(4), 5-30.

[5] Cacagna, E., Lacovone, L. and Rubiano, E. (2020). Women Entrepreneurs in Mexico: Breaking Sectoral Segmentation and increasing www.inegi.org. $\mathrm{mx} /$ programes/enamin/2012/?ps=macrodato Profits.

[6] Chen, C. C., Gene Greene, P., \& Crick, A. (1998). Does entrepreneurial self-efficacy distinguish entrepreneurs from managers? Journal of Business Venturing, 13(4), 295-316.

[7] Davidsson, P. (1995). Culture, structure and regional levels of entrepreneurship. Entrepreneurship \& Regional Development, 7(1), 41-62.

[8] Davidsson, P. and Wiklund, J. (1997), Values, beliefs and regional variations in new firm formation rates. Journal of Economic Psychology, 18, 179-199.
[9] Deaux, K., and Lafrance, M. (1998). Gender. In D. T. Gilbert, S. T. Fiske and G. Lindzey (Eds.). The Handbook of Social Psychology, Vol. 1: 788-827. Boston: McGraw Hill.

[10] Dharmendra, K. (2014). Socio-Cultural Influence on Women Entrepreneurs: A Study of Uttarakhand State. Int. J. of Trade and Commerce- IIARTC, 3(1), 127-139.

[11] Delmar, F., and Gunnarsson, J. (2000). How do self-employed parents of nascent entrepreneurs contribute? In: P.D. Reynolds, E. Autio, C.G. Brush, W.D., Bygrave; S., Manigart, H.J., Sapienza, K.G. Shaver (eds.) Frontiers of Entrepreneurship Research 2000, Babson College, Wellesley, MA, Arthur M. Blank Center for Entrepreneurship, pp.150-162.

[12] Eren, İ. (2012). Entrepreneurship and religion: An evaluation about Islam's perspective on entrepreneurship with Islam's main sources. Journal of Entrepreneurship and Development, 7(1), 4968.

[13] Fornahl, D. (2003), Entrepreneurial activities in a regional context. In: Fornahl, D. and Brenner, T. (eds.), Cooperation, Networks and Institutions in Regional Innovation Systems. Cheltenham: Edward Elgar, 38-57.

[14] Gibson, D. E. (2004). Role models in career development: New directions for theory and research. Journal of Vocational Behavior, 65

[15] Global Entrepreneurship Monitor (GEM). (2010). 2010 Report on Higher Expectation Entrepreneurship. Retrieved from www.gemconsortium.org (accessed on 1 June 2011)

[16] Janice Byrne, Salma Fattoum\& Maria Cristina Diaz Garcia. (2019) Role models and Women Entrepreneurs: entrepreneurial superwoman Has Her Say, journal of small Business Management, 57 (1) 154- 184 Doi:10./I//ijsbm.12426.

[17] Kim, P. H., \& Aldrich, H. E. (2005). Social capital and entrepreneurship. Foundations and Trends in Entrepreneurship, $1(2)$.

[18] Kim, P. H., Aldrich, H. E. \& Keister, L. A. (2006). Access (not) denied: The impact of financial, human, and cultural capital on entrepreneurial entry in the United States. Small Business Economics, 27(1): 5-22.

[19] Krumboltz, J., Mitchell, A., \& Jones, G. (1976). A social learning theory of career selection. 6 .

[20] Krueger, N., Reilly, M., \& Carsrud, A. (2000). Competing models of entrepreneurial intentions. Journal of Business Venturing, 15.

[21] Krueger, N. F. J. \& Dickson, P. R. (1993). Percieved self-efficacy and perceptions of opportunity and threats. Psychological Reports, $72,1235-1240$.

[22] Krueger, N. F. J., \& Dickson, P. R. (1994). How believing in ourselves increases risk taking: Perceived self-efficacy and opportunity recognition. Decision Sciences, 25(3), 385- 400.

[23] Lafuente, E., Vailliant, Y. and Rialp, J. (2007). Regional differences in the influence of role models : Comparing the entrepreneurial process of rural Catalonia, Regional Studies, 41(6), 779-795.

[24] Lent, R. W., Brown, S. D., \& Hackett, G. (1994). Toward a unified social cognitive theory of career and academic interests, choice, and performance. Journal of Vocational Behavior, 45, 79122.

[25] Mercy, N. (2013). Female Enterprise Development. Master Thesis in Business Administration.

[26] Mueller, P. (2006). Entrepreneurship in the Region: Breeding Ground for Nascent Entrepreneurs. In Small Business Economics, 27.

[27] Mwaura, A. T. W., Gathenya, J. W., \& Kihoro, J. (2015). Dynamics of Entrepreneurial Orientation on the Performance of Women Owned Enterprises in Kenya. International Journal of Academic Research in Business and Social Sciences, 5(9). http://doi.org/10.6007/IJARBSS/v5-i9/1794

[28] Naude, W. and Minniti, M. (2011). Examining the Entrepreneur Gender Gap. Economic Development, Female Entrepreneurs in Developing Countries.File://F:I...-United Nations University.htm

[29] Nauta, M. and Kokaly, M. (2001). Assessing Role Model Influences on Students' Academic and Vocational Decisions. Journal of Career Assessment, 9 (1), 81-99. 
[30] Noguera, M. (2012). Female entrepreneurship in Catalonia: an institutional approach. Doctoral Thesis (International Doctorate in Entrepreneurship and Management). Universitat Autonoma de Barcelona.

[31] Niels, B., Jolanda, H., Veronique, S., Mirjam, V. P., \& Ingrid, V. (2011). Entrepreneurship and Role Models. Tinbergen Institute Discussion Paper, 1-28

[32] Nworah, U. (2011). Culture and Igbo Business practices.Sahara Reporters, June20, 2011.

[33] Okafor, C., \& Mordi, C. (2010). Women Entrepreneurship Development in Nigeria: the Effect of Environmental Factors. Petroleum-Gas University of Ploiesti BULLETIN, Economic Sciences Series., 62(4), 79-92.

[34] Petro, M., Annastazia, M. \& Robert, G. M. (2014). The Effects of Socio-Cultural Factors on the Performance of Women Small and Medium Enterprises in Tanzania. Journal of Economics and Sustainable Development, 5(21), 89-98.

[35] Reynolds, P. D., Storey, D., \& Westhead, P. (1994). Crossnational Comparisons of the Variation in New Reynolds Firm Formation Rates. 28.

[36] Ruef, M., Aldrich, H. E., \& Carter, N. M. (2003). The Structure of Founding Teams: Homophily, strong ties, and the isolation among U.S. entrepreneurs. American Sociological Review.

[37] Shapiro, E., Haseltine, F., \& Rowe, M. (1978). Moving up: Role models, mentors, and the 'patron system'. Sloan Management Review, 6(1)

[38] Singh, S., Mordi, C., Okafor, C., \& Simpson, R. (2010). Challenges in Female Entrepreneurial Development-A Case Analysis of Nigerian Entrepreneurs. Journal of Enterprising Culture, 18(4). doi:10.1142/S0218495810000628

[39] SMEDAN \& NBS (2013). Selected findings of collaborative survey. Retrieved from https://www.smedan.gov.ng/images/PDF/2013-MSME-SurveySummary- Report.pdf
[40] Shapero, A., Sokol, L. (1982). The social dimensions of entrepreneurship. Encyclopedia of Entrepreneurship, (72-90). In C. A. Kent, D. L. Sexton and K. H. Vesper. Englewood Cliffs, N J, Prentice Hall.

[41] Scherer, R. F., Brodzinski, J. D., \& Wiebe, F. A. (1991). Examining the Relationship Between Personality and Entrepreneurial Carreer Preference. Entrepreneurship \& Regional Development, 3, 195-206.

[42] Sternberg, R. (2009). Regional dimensions of entrepreneurship. Foundations and Trends in Entrepreneurship 5, Now Publishers.

[43] Tundui, H. P. (2012). Gender and Small Business Growth in Tanzania: The Role of Hibitus: University of Groningen, Groningen, the Netherlands, 161.

[44] Van Auken, H., Fry, F. L., \& Stephens, P. (2006a). The Influence of Role Models on Entrepreneurial Intentions. Journal of Developmental Entrepreneurship, Vol. 11(2).

[45] Van Auken, H., Stephens, P., Fry, F. L., \& Silva, J. (2006b). Role Model Influences on Entrepreneurial Intentions. A comparison between USA and Mexico, International Entrepreneurship and Management Journal, 2(3).

[46] Vinesh, L. (2014). Role of women entrepreneurs in India. Global Journal of Finance and Management. 6(5) 473-480.

[47] Yusuf, L. (2013). Influence of gender and cultural beliefs on women entrepreneurs in developing economy. Scholarly Journal of Business Administration, ISSN 2276-7126 3(5). Retrieved from http:// www.scholarly-journals.com/SJBA.

[48] Wright, S., Wong, A. \& Newill, C. (1997). The Impact of Role Models on Medical Students. Journal of general internal medicine. 12. 53-6. 10.1007/s11606-006-0007-1.

[49] Wright, S., Wong, A. \& Newill, C. (1997). The Impact of Role Models on Medical Students. Journal of general internal medicine. 12. 53-6. 10.1007/s11606-006-0007-1. 